\title{
Anti-hyperglycemic and Anti-lipidemic activities of Diabac (a polyherbal formulation) in Streptozotocin-nicotinamide induced type 2 diabetic rats
}

\author{
Richa Agrawal, Rajesh Maheshwari", Ramachandran Balaraman and Avinash Seth \\ Department of Pharmacy, Sumandeep Vidyapeeth, Piparia, Vadodara, Gujarat, India.
}

\begin{abstract}
Aim: The objective of the work was to investigate the antidiabetic activity of Diabac (a polyherbal formulation) in streptozotocin-nicotinamide induced type 2 diabetic rats. Methods: Oral glucose tolerance test (OGTT) was performed to evaluate effect of Diabac on elevated glucose level. The type 2 diabetes was induced by overnight fasted rats by a single intraperitoneal (i.p.) injection of $65 \mathrm{mg} / \mathrm{kg}$ streptozotocin, $15 \mathrm{~min}$. after the i.p. administration of $110 \mathrm{mg} / \mathrm{kg}$ nicotinamide. The diabetic rats were treated with Diabac $(250,500$ and $1000 \mathrm{mg} / \mathrm{kg}$, p.o.) or glibenclamide $(5 \mathrm{mg} / \mathrm{kg}$, p.o) for four week. Various parameters were studied such as fasting blood sugar level, serum insulin levels, glycated hemoglobin $\left(\mathrm{HbA}_{1 \mathrm{C}}\right)$, serum lipid levels, se rum creatinine, urea, uric acid and liver glycogen. Results: Treatment with Diabac significantly reduced the blood sugar levels in OGTT. Diabetic rats showed a significant increase in the levels of glycated hemoglobin, serum lipids, serum creatinine, urea and uric acid, whereas there was a decrease in serum insulin, liver glycogen and HDL-C levels as compared to normal control rats. The administration of Diabac or glibenclamide significantly decreased the levels of glycated hemoglobin, TG, TC, LDL-C, serum creatinine, urea and uric acid, whereas there was an increase in the levels of liver glycogen and HDL-C as compared to diabetic control rats. However, the treatment with Diabac did not show any significant change in serum insulin levels as compared to diabetic control rats. Conclusion: These results of present study concluded that Diabac has anti-diabetic and anti-lipidemic activities which are responsible for its use in traditional medicine.
\end{abstract}

Key words: Diabac, Glycated hemoglobin, Liver glycogen, Serum lipids, Streptozotocin.

\section{SUMMARY}

- Administration of Diabac $(250,500$ and $5000 \mathrm{mg} / \mathrm{kg})$, a polyherbal formulation to the STZ-nicotinamide induced diabetes resulted in a decrease the levels of fasting blood sugar, glycated hemoglobin, TG, TC, LDL-C, serum creatinine, urea and uric acid, while there was an increase in the levels of liver glycogen and HDL-C as compared to diabetic control rats.

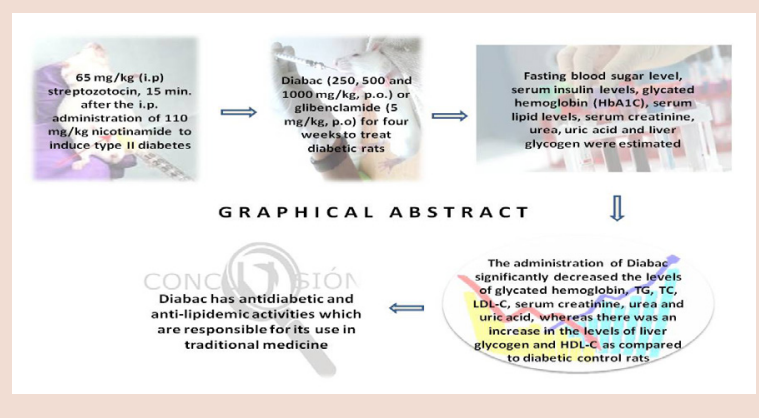

PICTORIAL ABSTRACT

Abbreviations used: $\mathrm{HbA}_{1 \mathrm{c}}$ : Glycated hemoglobin, TC: Total cholesterol, TG: Triglycerides, LDL-C: Low density lipoprotein-cholesterol, HDL: High density lipoprotein-cholesterol.

Correspondence:

Dr. Rajesh Maheshwari, Assistant Professor, Department of Pharmacy, Sumandeep Vidyapeeth, Piparia, Vadodara-391 760, Gujarat, India.

Email: rajpharma2007@gmail.com

DOI : 10.5530/pj.2015.5.6

\section{INTRODUCTION}

Diabetes mellitus is a metabolic disorder characterized by hyperglycemia resulting from the defects in insulin secretion, insulin resistance or both. ${ }^{1}$ It is considered to be one of the five foremost causes of death in the world. ${ }^{2}$ There are reports that incidence of diabetes mellitus was $2.8 \%$ in 2000 and is expected to be increase to $4.4 \%$ in $2030 .^{3}$ For a long time, diabetes mellitus has been treated with a number of medicinal plants or their extracts based on folklore medicine. ${ }^{4}$ The oral hypoglycemic agents (sulfonylurea, biguanide, thiazolidinedione, $\alpha$-glycosidase inhibitor and DPP-IV inhibitor) can produce several undesirable side effects and in addition, they are not suitable for use in pregnancy. ${ }^{5}$ Thus, the management of diabetes without any side effects is still a challenge. Therefore, the search for more effective and safer hypoglycemic agents has continued to be an important area of active research. Since, the oral hypoglycemic agents cause several side effects it has become a need to search for a new herbal drug with little side effects. ${ }^{6}$ Diabac contains herbal extract with known antidiabetic action (Table 1). ${ }^{7-16}$

In present study, we try to investigate antidiabetic effect of Diabac (a polyherbal formulation from Bacfo Pharmaceuticals India Limited, Noida) Since, there is no scientific evidence of this herbal formulation in experimentally induced type II diabetes.

\section{MATERIALS AND METHODS}

\section{Drugs and chemicals}

Diabac (Bacfo Pharmaceuticals India Limited, Noida), Streptozotocin, nicotinamide (Himedia, Mumbai, India) and Glibenclamide (USV Limited) are the main drugs used in present study. All biochemical kits were purchased from Span diagnostics Ltd, Surat, India and other chemicals and reagents used in the study were of analytical grade.

\section{Experimental animals}

Albino Wistar rats (200-250 g) of either sex were obtained from Zydus Research Centre, Ahmedabad. All animals were maintained under standardized condition (12-h light/dark cycle, $24 \pm 2^{\circ} \mathrm{C} \&$ humidity $35-60 \%$ ) and they were provided with standard pellet diet and water ad libitum. The rats were left for $48 \mathrm{~h}$ for adaptation prior to the beginning of the experiment. The study was approved by Institutional Animal Ethics Committee (IAEC) and carried out in accordance with CPCSEA (Committee for the Purpose of Control and Supervision of Experiment on Animal) guidelines. 


\begin{tabular}{cccc} 
Table 1: Composition of Diabac (A polyherbal formulation) \\
\hline Ingredients & Botanical name & Part used & Weight $(\mathbf{m g})$ \\
\hline Gurmar & Gymnema sylvestre & Whole Plant & 100 \\
Jamunmingi & Eugenia jamolana & Whole Plant & 100 \\
Bilvapatra & Aegle maemelos & Whole Plant & 100 \\
Nyagrodha & Ficus bengalensis & Whole Plant & 100 \\
Shilajeet & Asphaltum & Whole Plant & 100 \\
\hline
\end{tabular}

Bhavna Dravya: Processed with the extracts of Karela (Memordica charantia), Bhumi Amla (Phyllanthus niruri), Neemswaras (Azadirachta indica), Triphla \& Vijaysar (Pterocarpus masrsupium)

\section{Acute toxicity study}

At the basis OECD guideline no. 423, the acute oral toxicity was carried out in albino Wistar rats of either sex weighing 200-250g. ${ }^{17}$ Diabac was given at the dose of $(100,200,500,1000,2000$ and $5000 \mathrm{mg} / \mathrm{kg}$, p.o.) for 3 animals and the signs and symptoms were observed after $0,30,60,120$, 180, $240 \mathrm{~min}$ and then once a day for next 14 days.

\section{Oral glucose tolerance test (OGTT)}

Oral glucose tolerance test was performed in overnight (12h) fasted normal rats. ${ }^{18}$ Rats were divided into five groups of six of each. Groups 1 received drinking water, Groups 2 received glibenclamide $(5 \mathrm{mg} / \mathrm{kg}$, p.o.), group 3-5 received Diabac (250, 500 and $1000 \mathrm{mg} / \mathrm{kg}$, p.o.). Glucose $(2 \mathrm{~g} / \mathrm{kg}$, p.o.) was fed $30 \mathrm{~min}$ prior to the administration of abovementioned treatments. Blood glucose levels were measured by collecting the blood samples from the tail vein and they were collected at 0 , $30,60,90$ and 120 minutes after the glucose loading and blood glucose levels were measured.

\section{Induction of type 2 diabetes}

Sreptozotocin $(65 \mathrm{mg} / \mathrm{kg}$, i.p.) and nicotinamide $(110 \mathrm{mg} / \mathrm{kg}$, i.p.) were administered to overnight fasting albino Wistar rats (200-250 g) to induce Type 2 diabetes. Nicotinamide (dissolved in normal saline) was given first and 15 minutes later streptozotocin (dissolved in citrate buffer, pH 4.5) was administered. ${ }^{19,20}$ Hyperglycemia was confirmed by elevated blood glucose levels at $72 \mathrm{~h}$ and then on day 7 after injection and only animals with fasting blood glucose level greater than $200 \mathrm{mg} / \mathrm{dl}$ were selected for antidiabetic study.

\section{Experimental design}

The rats were divided into six groups each consisting of six animals.

Group I: Normal control rats (distilled water $1 \mathrm{ml} / \mathrm{kg}$, p.o.).

Group II: Diabetic control rats.

Group III: Diabetic rats treated with glibenclamide (5 mg/kg, p.o.).

Group IV: Diabetic rats treated with Diabac (250 mg/kg, p.o.)

Group V: Diabetic rats treated with Diabac (500 mg/kg, p.o.)

Group VI: Diabetic rats treated with Diabac (1000 mg/kg, p.o.)

All the aforementioned treatments were started one week (7 days) after induction of diabetes and treatments continued for 28 days.

The fasting blood sugar levels were measured on 1, 7, 14, 21 and 28 days periodically. Urine volume and urine glucose contents were estimated. At the end of the experiments, blood samples were collected from the retro orbital plexus of rats under light ether anesthesia, using glass capillaries and stored in with or without disodium ethylene diamine tetra-acetate for estimation of biochemical parameters. After, allowing the blood to clot for serum separation for 15 minutes, it was centrifuged at 5000 rpm for 20 minutes for separation of serum. Then the serum was stored at $-20^{\circ} \mathrm{C}$ until further estimation.
Blood glucose, glycated hemoglobin $\left(\mathrm{HbA}_{1 \mathrm{C}}\right)$, hemoglobin $(\mathrm{Hb})$ were estimated using whole blood. The total cholesterol (TC), triglycerides (TG), low density lipoprotein (LDL-C), high density lipoprotein (HDL), serum creatinine, urea and uric acid were estimated from serum using standard diagnostic kit. The serum insulin was determined by radioimmunoassay method. ${ }^{21}$ Glycogen level in liver was determined as according to the method of Roe et. al. . $^{2}$

\section{Histopathology}

After sacrifice, pancreas tissues of each group were rapidly dissected out and washed immediately with saline and fixed in $10 \%$ phosphate buffered formalin. Paraffin-embedded specimens were cut into $5 \mu \mathrm{m}$-thick sections and stained with hematoxylin and eosin (H\&E). The sections were examined under the light microscope (Olympus BX10, Tokyo, Japan) for the presence of histopathological changes and photomicrographs (Olympus DP12 camera, Japan) were taken. The observer performing histopathological evaluation was blinded to the animal treatment groups.

\section{Statistical analysis}

All the data are expressed as mean \pm SEM $(n=6)$. The statistical significance between more than two groups was tested using one-way ANOVA followed by the Bonferroni multiple comparisons post test using a computer-based fitting program (Prism, GraphPad version 5, GraphPad software, Inc). The significance level was set at $\mathrm{P}<0.05$ for all tests.

\section{RESULTS}

\section{Acute oral toxicity}

The administration of Diabac up to a dosage $5000 \mathrm{mg} / \mathrm{kg}$ did not show any sign of toxicity and no mortality for 14 days. Therefore, the pharmacological studies were carried out using $1 / 20^{\text {th }}(250 \mathrm{mg} / \mathrm{kg}), 1 / 10^{\text {th }}(500$ $\mathrm{mg} / \mathrm{kg})$ and $1 / 5^{\text {th }}(1000 \mathrm{mg} / \mathrm{kg})$ dose levels of Diabac.

\section{Effect of Diabac on oral glucose tolerance test (OGTT)}

Glucose challenge to normal rats increased blood glucose levels with maximum at $60 \mathrm{~min}$ and slight reduction in blood glucose was observed at 90 min onwards. The treatment with Diabac or glibenclamide improved glucose tolerance significantly at $60 \mathrm{~min}$ to $120 \mathrm{~min}$ compared to normal control animals (Table 2).

\section{Effect of Diabac on fating blood glucose levels}

The effect of Diabac on fasting blood glucose level of diabetic rats is shown in Table 3. Diabetic rats showed a significant increase in the fasting blood glucose levels as compared to normal control rats. At day 14 onwards, treatment with Diabac $(250,500$ and $1000 \mathrm{mg} / \mathrm{kg}$ ) showed a significant dose dependent decrease in blood glucose levels as compared 
Table 2: Effect of Diabac on oral glucose tolerance test in non-diabetic rats

\begin{tabular}{ccccccc}
\multirow{2}{*}{ Groups } & Treatment & \multicolumn{4}{c}{ Blood glucose (mg/dl) } \\
\cline { 3 - 6 } & & 0 min & 30 min & 60 min & 90 min \\
\hline 1 & Normal control & $102.3 \pm 3.25$ & $127.2 \pm 3.60$ & $147.0 \pm 7.90$ & $115.7 \pm 7.04$ & $107.5 \pm 2.99$ \\
2 & Glibenclamide $(5 \mathrm{mg} / \mathrm{kg})$ & $95.83 \pm 2.18$ & $104.5 \pm 4.07^{* *}$ & $96.83 \pm 4.84^{* * *}$ & $85.67 \pm 5.14^{* * *}$ & $91.33 \pm 4.95^{*}$ \\
3 & Diabac (250 mg/kg) & $102.3 \pm 4.21$ & $113.8 \pm 5.69$ & $137.5 \pm 5.57^{*}$ & $117.0 \pm 2.28$ & $111.3 \pm 2.18$ \\
4 & Diabac (500 mg/kg) & $98.17 \pm 3.71$ & $126.2 \pm 5.24$ & $125.3 \pm 4.75^{* *}$ & $112.3 \pm 3.13^{*}$ & $103.0 \pm 3.36^{*}$ \\
5 & Diabac (1000 mg/kg) & $96.50 \pm 2.66$ & $109.2 \pm 2.88^{*}$ & $121.0 \pm 2.76^{* *}$ & $107.7 \pm 2.31^{*}$ & $99.50 \pm 1.60^{*}$ \\
\hline
\end{tabular}

Values are expressed in mean \pm S.E.M $(n=6)$, where ${ }^{*} \mathrm{P}<0.05,{ }^{* *} \mathrm{P}<0.01,{ }^{* * *} \mathrm{P}<0.001$ as compared to normal control.

Table 3: Effect of Diabac on fasting blood glucose levels in STZ-nicotinamide induced type II diabetes

\begin{tabular}{|c|c|c|c|c|c|c|}
\hline \multirow{2}{*}{ Groups } & \multirow{2}{*}{ Treatment } & \multicolumn{5}{|c|}{ Fasting Blood glucose (mg/dl) } \\
\hline & & Day 1 & Day 7 & Day 14 & Day 21 & Day 28 \\
\hline 1 & Normal control & $73.67 \pm 1.706$ & $76.83 \pm 1.92$ & $80.17 \pm 1.77$ & $74.67 \pm 3.373$ & $87.33 \pm 5.80$ \\
\hline 2 & Diabetic control & $243.7 \pm 12.73$ & $254.2 \pm 15.13^{\# \# *}$ & $279.5 \pm 17.61^{\# \# \#}$ & $311.8 \pm 24.17^{\# \# \#}$ & $319.2 \pm 23.96^{\# \# \#}$ \\
\hline 3 & Glibenclamide (5 mg/kg) & $297.7 \pm 26.70$ & $268.7 \pm 16.52$ & $223.2 \pm 6.45^{* *}$ & $189.8 \pm 15.54^{* * *}$ & $132.7 \pm 10.24^{* * *}$ \\
\hline 4 & Diabac (250 mg/kg) & $322.5 \pm 33.77$ & $314.2 \pm 30.27$ & $217.8 \pm 10.5^{* *}$ & $208.3 \pm 9.03^{x+*+}$ & $207.5 \pm 8.21^{*+*}$ \\
\hline 5 & Diabac (500 mg/kg) & $293.0 \pm 19.90$ & $304.8 \pm 23.45$ & $202.2 \pm 8.69^{* * * *}$ & $189.5 \pm 7.63^{* * *}$ & $169.8 \pm 8.99^{* * *}$ \\
\hline 6 & Diabac (1000 mg/kg) & $288.8 \pm 15.75$ & $301.2 \pm 21.99$ & $200.3 \pm 5.06$ & $185.2 \pm 11.87^{4 * *}$ & $119.2 \pm 6.4^{\mathrm{cx*}}$ \\
\hline
\end{tabular}

Values are expressed in Mean \pm S.E.M $(\mathrm{n}=6)$, where ${ }^{\# \# *} \mathrm{P}<0.001$ as compared to normal control; ${ }^{*} \mathrm{P}<0.05,{ }^{* *} \mathrm{P}<0.01$, ${ }^{* * *} \mathrm{P}<0.001$ as compared to diabetic control.

Table 4: Effect of Diabac on body weight, urine volume and urine glucose in STZ-nicotinamide induced type II diabetes

\begin{tabular}{ccccccc}
\hline Groups & Treatment & Initial body weight $(\mathbf{g})$ & Final body weight $(\mathbf{g})$ & Urine Volume $(\mathrm{ml})$ & Urine glucose \\
\hline 1 & Normal control & $275.0 \pm 10.25$ & $266.7 \pm 11.45$ & $20.83 \pm 1.24$ & Nil \\
2 & Diabetic control & $216.7 \pm 10.54$ & $173.3 \pm 8.02^{* * *}$ & $54.33 \pm 2.81^{* * *}$ & ++ \\
3 & Glibenclamide $(5 \mathrm{mg} / \mathrm{kg})$ & $213.3 \pm 6.146$ & $203.3 \pm 7.149$ & $25.00 \pm 1.34^{* * *}$ & Nil \\
4 & Diabac $(250 \mathrm{mg} / \mathrm{kg})$ & $211.7 \pm 8.333$ & $185.0 \pm 9.91^{* *}$ & $43.17 \pm 1.27^{* * *}$ & + \\
5 & Diabac $(500 \mathrm{mg} / \mathrm{kg})$ & $220.0 \pm 10.65$ & $204.2 \pm 7.79$ & $35.00 \pm 0.93^{* * *}$ & Nil \\
6 & Diabac $(1000 \mathrm{mg} / \mathrm{kg})$ & $216.7 \pm 8.433$ & $209.2 \pm 8.40$ & $28.33 \pm 1.02^{* * *}$ & Nil \\
\hline
\end{tabular}

Values are expressed as Mean + S.E.M ( $\mathrm{n}=6)$, Where, ${ }^{* \# *} \mathrm{P}<0.001$ as compared to normal control; ${ }^{* *} \mathrm{P}<0.01,{ }^{* * *} \mathrm{P}<0.001$ as compared to diabetic control.

$(+)$ - Trace elements of sugar and $(+++)$ - more than $2 \%$ of sugar.

to diabetic control rats.

\section{Effect of Diabac on body weight, urine volume and urine glucose}

Diabetic rats showed a significant decrease $(\mathrm{P}<0.001)$ in body weight compared to normal control rats. However, treatment with Diabac (500 and $1000 \mathrm{mg} / \mathrm{kg}$, p.o.) or glibenclamide did not show any significant reduction in body weight as compared to diabetic control, while Diabac $(250 \mathrm{mg} / \mathrm{kg})$ treated rats showed a significant reduction in body weight. Administration of Diabac or glibenclamide to diabetic rats showed a significant $(\mathrm{P}<0.001)$ reduction in urine volume as compared to diabetic control rats. An effect of Diabac or glibenclamide on urine glucose is shown in Table 4.

\section{Effect of Diabac on Hemoglobin, Glycated hemoglobin, serum insulin and liver glycogen levels}

Diabetic rats showed a significant $(\mathrm{P}<0.001)$ elevation in the level of glycated hemoglobin $\left(\mathrm{HbA}_{1 \mathrm{C}}\right)$ and reduction in the level of hemoglobin $\mathrm{Hb}$, serum insulin as compared to normal control rats. The treatment with Diabac (250, 500 and $1000 \mathrm{mg} / \mathrm{kg}$, p.o.) or glibenclamide $(5 \mathrm{mg} / \mathrm{kg}$, p.o.) showed a significant $(\mathrm{P}<0.001)$ reduction in levels of glycated hemoglobin and an increase in the level of $\mathrm{Hb}$ at dose dependant manner. In contrast, treatment with Diabac did not show any significant alteration in serum insulin levels as compared to diabetic untreated rats. Liver glycogen levels of diabetic rats were significantly decreased as compared to normal control rats. The treatment with Diabac (500 and $1000 \mathrm{mg} /$ $\mathrm{kg}$ ) showed a significant $(\mathrm{P}<0.001)$ increase in levels of liver glycogen as compared to diabetic control rats. In addition, Diabac $(250 \mathrm{mg} / \mathrm{kg})$ treated rats did not show any significant alteration in liver glycogen content as compared to diabetic control rats (Table 5).

\section{Effect of Diabac on serum lipid levels}

Diabetic rats showed a significant $(\mathrm{P}<0.001)$ increase in the level of TG, TC and LDL-C and a reduction in level of HDL-C as compared to normal control rats. Treatment with Diabac (500 and $1000 \mathrm{mg} / \mathrm{kg}$ ) showed a significant reduction in level of TG $(\mathrm{P}<0.001)$, TC $(\mathrm{P}<0.001)$, LDL-C $(\mathrm{P}<0.001)$ and an increase in HDL-C $(\mathrm{P}<0.01 ; \mathrm{P}<0.001)$ levels in diabetic rats when compared to diabetic control rats. Moreover, treatment with Diabac $(250 \mathrm{mg} / \mathrm{kg})$ showed a significant decrease in levels of TG $(\mathrm{P}<0.001)$, TC $(\mathrm{P}<0.05)$, LDL-C $(\mathrm{P}<0.01)$ and did not show any sig- 
Table 5: Effect of Diabac on hemoglobin $(\mathrm{Hb})$, glycated hemoglobin, serum insulin and liver glycogen levels in STZ-nicotinamide induced type II diabetes

\begin{tabular}{|c|c|c|c|c|c|}
\hline Groups & Treatment & $\begin{array}{c}\mathrm{Hb} \\
(\mathrm{g} / \mathrm{dl})\end{array}$ & $\begin{array}{c}\text { Glycated hemoglobin } \\
\left(\mathrm{HbA}_{1 \mathrm{c}} \%\right)\end{array}$ & $\begin{array}{l}\text { Serum insulin } \\
(\mathrm{mU} / \mathrm{L})\end{array}$ & $\begin{array}{c}\text { Liver glycogen } \\
(\mathrm{mg} / \mathrm{g})\end{array}$ \\
\hline 1 & Normal control & $14.67 \pm 0.28$ & $6.183 \pm 0.17$ & $1.01 \pm 0.12$ & $55.66 \pm 2.38$ \\
\hline 2 & Diabetic control & $8.16 \pm 0.56^{\# \# \#}$ & $11.75 \pm 0.26^{\# \# \#}$ & $0.27 \pm 0.04^{\# \# \#}$ & $7.86 \pm 1.04^{\# \# \#}$ \\
\hline 3 & Glibenclamide (5 mg/kg) & $12.48 \pm 0.30^{* * * *}$ & $6.78 \pm 0.11^{* * *}$ & $0.76 \pm 0.03^{* *}$ & $48.33 \pm 4.58^{\ldots \ldots+}$ \\
\hline 4 & Diabac (250 mg/kg) & $11.27 \pm 0.62^{* * *}$ & $9.31 \pm 0.10^{* * * *}$ & $0.35 \pm 0.04$ & $16.11 \pm 0.92$ \\
\hline 5 & Diabac (500 mg/kg) & $12.93 \pm 0.28^{* * x}$ & $8.27 \pm 0.11^{* * *}$ & $0.39 \pm 0.03$ & $30.04 \pm 1.80^{* \times *}$ \\
\hline 6 & Diabac $(1000 \mathrm{mg} / \mathrm{kg})$ & $14.10 \pm 0.52^{* * *}$ & $7.18 \pm 0.13^{* * * *}$ & $0.40 \pm 0.03$ & $47.21 \pm 3.47^{* * x}$ \\
\hline
\end{tabular}

Values are expressed as Mean + S.E.M $(\mathrm{n}=6)$. Where, ${ }^{* * *} \mathrm{P}<0.001$ as compared to normal control; ${ }^{* *} \mathrm{P}<0.01,{ }^{* * *} \mathrm{P}<0.001$ as compared to diabetic control.

Table 6: Effect of Diabac on serum lipid levels in STZ-nicotinamide induced type II diabetes

\begin{tabular}{|c|c|c|c|c|c|}
\hline Groups & Treatment & $\mathrm{TG}(\mathrm{mg} / \mathrm{dl})$ & $\mathrm{TC}(\mathrm{mg} / \mathrm{dl})$ & LDL-C (mg/dl) & HDL-C (mg/dl) \\
\hline 1 & Normal control & $99.29 \pm 2.76$ & $124.4 \pm 6.58$ & $44.49 \pm 8.14$ & $60.0 \pm 3.65$ \\
\hline 2 & Diabetic control & $181.6 \pm 3.53^{\# \# \#}$ & $294.0 \pm 12.26^{\# \# \#}$ & $237.7 \pm 10.53^{\# \# \#}$ & $20.0 \pm 1.82^{\# \# \#}$ \\
\hline 3 & Glibenclamide (5 mg/kg) & $106.7 \pm 2.06^{* * *}$ & $137.0 \pm 5.86^{*+*}$ & $62.32 \pm 3.73^{x+*}$ & $53.33 \pm 5.27^{*+*}$ \\
\hline 4 & Diabac (250 mg/kg) & $162.6 \pm 1.11^{* * *}$ & $255.7 \pm 4.78^{*}$ & $197.4 \pm 5.11^{* *}$ & $25.83 \pm 2.38$ \\
\hline 5 & Diabac (500 mg/kg) & $142.5 \pm 1.61^{* * *}$ & $203.0 \pm 6.04^{* *+}$ & $133.3 \pm 5.55^{* * *}$ & $41.17 \pm 1.53^{* *}$ \\
\hline 6 & Diabac (1000 mg/kg) & $119.4 \pm 1.86^{* * *}$ & $138.0 \pm 5.92^{* * *}$ & $55.75 \pm 2.97^{* * *}$ & $58.33 \pm 4.01^{* * *}$ \\
\hline
\end{tabular}

Values are expressed as Mean + S.E.M ( $\mathrm{n}=6$ ). Where, \#\#\# $\mathrm{P}<0.001$ as compared to normal control; ${ }^{\mathrm{P}}<0.05$, ${ }^{* *} \mathrm{P}<0.01$, " ${ }^{* * *} \mathrm{P}<0.001$ as compared to diabetic control.

Table 7: Effect of Diabac on serum creatinine, urea and uric acid in STZ-nicotinamide induced type II diabetes

\begin{tabular}{ccccc}
\hline Groups & Treatment & Serum creatinine $(\mathrm{mg} / \mathrm{dl})$ & Urea $(\mathrm{mg} / \mathrm{dl})$ & Uric acid $(\mathrm{mg} / \mathrm{dl})$ \\
\hline 1 & Normal control & $0.84 \pm 0.03$ & $30.63 \pm 1.23$ & $2.88 \pm 0.27$ \\
2 & Diabetic control & $1.85 \pm 0.05 \# \# \#$ & $59.93 \pm 1.49 \# \# \#$ & $8.26 \pm 0.16 \# \# \#$ \\
3 & Glibenclamide $(5 \mathrm{mg} / \mathrm{kg})$ & $0.87 \pm 0.02^{* * *}$ & $36.64 \pm 1.43^{* * *}$ & $3.30 \pm 0.20^{* * *}$ \\
4 & Diabac $(250 \mathrm{mg} / \mathrm{kg})$ & $1.65 \pm 0.02^{*}$ & $51.32 \pm 0.88^{* * *}$ & $7.86 \pm 0.17$ \\
5 & Diabac $(500 \mathrm{mg} / \mathrm{kg})$ & $1.55 \pm 0.02^{* * *}$ & $42.97 \pm 1.50^{* * *}$ & $7.19 \pm 0.29^{*}$ \\
6 & Diabac $(1000 \mathrm{mg} / \mathrm{kg})$ & $0.89 \pm 0.03^{* * *}$ & $35.86 \pm 1.09^{* * *}$ & $4.12 \pm 0.22^{* * *}$ \\
\hline
\end{tabular}

Values are expressed as Mean + S.E.M $(n=6)$. Where, ${ }^{\# \# *} \mathrm{P}<0.001$ as compared to normal control; ${ }^{*} \mathrm{P}<0.05,{ }^{, *} \mathrm{P}<0.01,{ }^{* * *} \mathrm{P}<0.001$ as compared to diabetic control.

nificant changes in HDL-C level as compared to diabetic untreated rats (Table 6).

\section{Effect of Diabac on serum creatinine, urea and uric acid}

There was a significant $(\mathrm{P}<0.001)$ increase in the level of serum creatinine, urea and uric acid in diabetic control rats as compared to normal control rats. The administration of Diabac (500 and $1000 \mathrm{mg} / \mathrm{kg}$ ) showed a significant decrease in the level of serum creatinine $(\mathrm{P}<0.001)$, urea $(\mathrm{P}<0.001)$ and uric acid $(\mathrm{P}<0.05 ; \mathrm{P}<0.001)$ as compared to diabetic control rats. In addition, treatment with Diabac $(250 \mathrm{mg} / \mathrm{kg})$ showed a significant decrease in levels of serum creatinine $(\mathrm{P}<0.05)$, urea $(\mathrm{P}<0.001)$ and did not show any significant differences in uric acid level as compared to diabetic untreated rats (Table 7).

\section{Histopathological study}

In normal control rats, appearance of pancreas was shown normal. Pancreas of diabetic control rats showing reduced islet cells. However, the treatment with Diabac showed a recovery of islet cells to near normal appearance (Figure 1).

\section{DISCUSSION}

Administration of streptozotocin-nicotinamide caused diabetes, which may be because of destruction of beta cells of the islet of Langerhans of the pancreas..$^{23}$ Excessive production and decreased utilization of glucose by the tissue are the fundamental basis of hyperglycemia in diabetes mellitus. ${ }^{24}$ When Diabac was administered to glucose loaded overnight fasted normal rats, hypoglycemia was observed after $60 \mathrm{~min}$. The reduction in blood glucose levels was reached at its maximum at $2 \mathrm{~h}$. In current study, administration of Diabac showed a significant reduction in blood glucose levels in streptozotocin-nicotinamide induced hyperglycemia. This effect might be due to diminish hepatic glycogenolysis, gluconeogenesis and increased utilization of glucose by the tissues.

In diabetic control rats, glycated hemoglobin levels were found to be increased as compared to normal control rats due to the persistent hyper- 

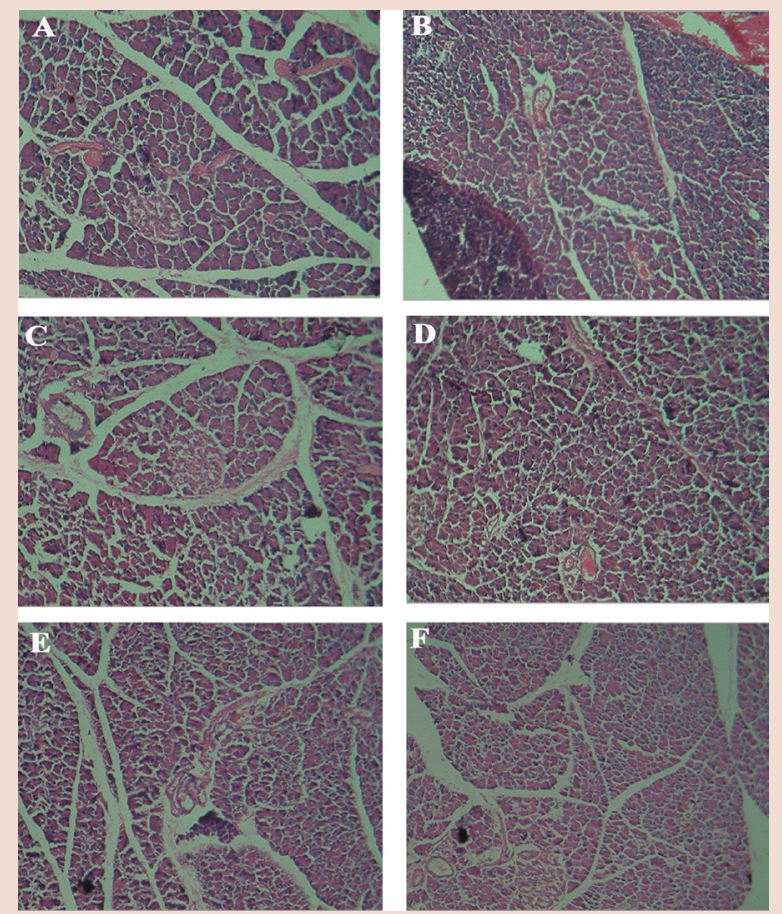

Figure 1: Photomicrograph of pancreas of rats

(A) Normal control group; (B) Diabetic control group; (C) Diabetic + glibenclamide; (D) Diabetic + Diabac (250 mg/kg); (E) Diabetic + Diabac (500 mg/kg); (F) Diabetic + Diabac (1000 mg/kg).

glycemia. It was previously reveled that elevation in non- enzymatic and autooxidation glycosylation in one of the probable mechanisms concerning the hyperglycemia and the vascular complications. ${ }^{25}$ Treatment with Diabac showed a significant reduction in the glycated hemoglobin levels. The ability of Diabac to reduce glycated hemoglobin levels in diabetic rats showed it's potentiality to prevent the diabetic associated complication. In diabetes, insulin deficiency leads to decrease in protein synthesis in all tissue and thus the synthesis of hemoglobin is also reduced. ${ }^{26}$ Administration of Diabac significantly increased hemoglobin levels in diabetic rats.

Streptozotocin-nicotinamide induced diabetes is characterized by severe reduction in body weight due to increased the muscle destruction or degradation of structural proteins. ${ }^{27}$ When diabetic rats were treated with Diabac, it showed an improvement in body weight as compared to untreated diabetic rats, which may be due to its protective effect in controlling the muscle wasting i.e. reversal of gluconeogenesis and the improvement in glycemic control.

Coronary heart disease and cerebrovascular disease are more common in diabetes. The atherogenic situation is proceeding at a more rapid rate in diabetic than non-diabetic subjects. ${ }^{28}$ The elevation in levels of triglycerides, total cholesterol, LDL-C and decreased HDL-C levels were reported in diabetic condition. ${ }^{29}$ In current study, administration of Diabac significantly decreased elevated levels of triglycerides, total cholesterol, LDL-C and increased level of HDL- $\mathrm{C}$ in diabetic rats as compared to diabetic control rats. Lipid lowering effect of Diabac might be helpful in controlling diabetic linked complication.

Protein glycation in diabetes might be accountable for muscle wasting and increased release of purine, major source of uric acid, as well as increased the activity of xanthine oxidase. ${ }^{30,31}$ Administration Diabac significantly reduced the serum creatinine, urea and uric acid levels in diabetic rats. These finding supports that Diabac improved kidney function in diabetic condition and for that reason, it helps to prevent diabetic related early renal damage.
In earlier study, it has been observed that hepatic glycogen is decreased during diabetes. ${ }^{32}$ In the study, deficiency of insulin in the diabetic condition may result in the inactivation of glycogen synthase. The significant increase in hepatic glycogen content of Diabac treated diabetic rats may be because of the reactivation of glycogen synthase system. Histopathological studies also supported our results. Diabetic rats showed reduced islet cells, which were restored to normal upon treatment with Diabac. There were no alterations found in normal rats.

\section{CONCLUSION}

From this study, it was concluded that Diabac has a significant antidiabetic effect. The Diabac also showed improvement in lipid profile, body weight and renal function in diabetic condition. Therefore it might be helpful in preventing diabetic associated complication. Our present investigation supports the conventional use of Diabac in the management of diabetes.

\section{ACKNOWLEDGEMENT}

We are sincerely thankful to Bacfo Pharmaceuticals India limited, Noida for providing financial support and their product sample to carry out the study.

\section{CONFLICT OF INTEREST}

We declare that we have no conflict of interest.

\section{REFERENCES}

1. American Diabetes Association. Diagnosis and classification of diabetes mellitus. Diabetes Care 2007; 30(1): S42-7.

2. Gipsen WH, Biessels GJ. Cognition and synaptic plasticity in diabetes mellitus. Trends Neurosci. 2000; 23(11): 542-9.

3. Wild S, Roglic G, Green A, Sicree R, King H. Global prevalence of diabetes estimates for the year 2000 and projections for 2030. Diabetes Care. 2004; 27(5): 1047-53.

4. Akhtar FM, Ali MR. Study of anti-diabetic effect of a compound medicinal plant prescription in normal and diabetic rabbits. J Pak Med Assoc. 1984; 34(8): 239-43.

5. Larner J. The pharmacological basis of therapeutics. $7^{\text {th }}$ ed. New York: Mac Millan; 1985.

6. Kim SH, Hyun SH, Choung SY. Antidiabetic effect of cinnamon extract on blood glucose in db/db mice. J Ethnopharmacol. 2006; 104(1): 119-23.

7. Shanmugasundaram ER. Gymnema Sylvestre for Diabetes. J Ethnopharmacol. 1990; 30(3): 265-79.

8. Ravi K, Sivagnanam K, Subramanian SJ. Anti-diabetic activity of Eugenia jambolana seed kernels on streptozotocin-induced diabetic rats. Med Food. 2004; 7(2): 187-91.

9. Ponnachan PT, Paulose CS, Panikkar KR. Effect of leaf extract of Aegle marmelose in diabetic rats. Indian J Exp Bio. 1993; 31(4): 345-7.

10. Singh RK, Mehta S, Jaiswal D, Rai PK, Watal G. Antidiabetic effect of Ficus bengalensis aerial roots in experimental animals. J Ethnopharmacol. 2009; 123(1): 110-4.

11. Chattopadhyay RR, Chattopadhyay RN, Nandy AK, Poddar G, Maitra SK. A Preliminary report on antihyperglycemic effect of a fraction of fresh leaves of Azadirachta indica (Beng. Neem). Bull Calcutta Sch Trop Med. 1987; 35(2): 29-33.

12. Singh N, Tyagi SD, Agarwal SC. Effects of long term feeding of acetone extract of Momordica charantia (whole fruit powder) on alloxan diabetic albino rats. Indian J Physiol Pharmacol. 1989; 33(2): 97-100.

13. Manickam M, Ramanathan M, Jahromi MA, Chansouria JP, Ray AB. Antihyperglycemic activity of phenolics from Pterocarpus marsupium. J Nat Prod. 1997; 60(6): 609-10.

14. Okoli CO, Ibiam AF, Ezike AC, Akah PA, Okoye TC. Evaluation of antidiabetic potential of Phyllanthus niruri in alloxan diabetic rats. Afr J Boitechnol. 2010; 9(2): 248-59.

15. Manosroia J, Mosesb ZZ, Manosroid W, Manosroia A. Hypoglycemic activity of Thai medicinal plants selected from the Thai/Lanna Medicinal Recipe Database MANOSROI II. J Ethnopharmacol. 2011; 138(1): 92-8.

16. Grover JK, Yadav S, Vats V. Medicinal plants of India with anti-diabetic potential. J Ethnopharmacol. 2002; 81(1): 81-100.

17. OECD, 2002. Acute oral toxicity. Acute oral toxic class method guideline 423 adopted 23.03.1996. In: Eleventh Addendum To The OECD Guidelines for the Testing of Chemicals Organisation for Economical Co-Operation and Development, Paris; 2000 June.

18. Bonner-weir S. Morphological evidence of pancreatic polarity of beta cells within islets of Langerhans. Diabetes 1988; 37(5): 616-21.

19. Maheshwari RA, Khatri K, Balaraman R, Seth AK. Antidiabetic activity of Dibolin a polyherbal formulation in streptozotocin-nicotinamide induced type 2 diabetic rats. Int 
J Pharm Pharm Sci. 2014; 6(2): 893-7.

20. Maheshwari RA, Balaraman R, Sen AK, Seth AK. Effect of coenzyme $\mathrm{Q} 10$ alone and its combination with metformin on streptozotocin-nicotinamide induced diabetic nephropathy in rats. Indian J Pharmacol. 2014; 46(6): 627-32.

21. Flier JS, Kahn CR, Roth J. Receptors, antireceptors antibodies and mechanisms of insulin resistance. N Eng J Med. 1979; 300(8): 413-9.

22. Roe JH, Dailey RE. Determination of Glycogen with the Anthrone Reagent. Anal Biochem. 1996; 15(2): 245-50

23. Kavalali G, Tuncel H, Goksel S, Hatemi MH. Hypoglycemic activity of Urtica pilulifera in streptozotocin-diabetic rats. J Ethnopharmacol. 2002; 84(2): 241-5.

24. Latner A. In: Clinical Biochemistry. Saunders, Philadelphia; 1985. p. 48.

25. Hall PM, Cook JGH, Sheldon J, Rutherford SM, Gould BJ. Glycosylated hemoglobin and glycosylated plasma proteins in the diagnosis of diabetes mellitus and impaired glucose tolerance. Diabetes Care. 1984; 7(2): 391-3.

26. Verma N, Amresh G, Sahu PK, Mishra N, Singh AP, Rao et al. Antihyperglycemic activity, antihyperlipedemic activity, haematological effects and histopathological analysis of Sapindus mukorossi Gaerten fruits in streptozotocin induced diabetic rats. Asian
Pac J Trop Med. 2012; 5(7): 518-22.

27. Irudayaraj SS, Sunil C, Duraipandiyan V, Ignacimuthu S. Antidiabetic and antioxidant activities of Toddalia asiatica (L) Lam. Leaves in Streptozotocin induced diabetic rats. J Ethnopharmacol. 2012; 143(2): 515-23.

28. Maser RE, Wolfson SK, Ellis D, Stein EA, Drash AL, Becker DJ, et al. Cardiovascular disease and arterial calcification in insulin-dependent diabetes mellitus: Interrelations and risk factor profiles. Pittsburgh epidemiology of diabetic complication study-V. Arterioscler Thromb. 1991; 11(4): 958-65.

29. Howard BV, Robbins DC, Sievers ML, Lee ET, Rhoades D, Devereux RB, et al. LDL cholesterol as a strong predictor of coronary heart disease in diabetic individuals with insulin resistance and low LDL: the strong heart study. Arterioscler Thrombo Vasc Biol. 2000; 20(3): 830-5.

30. Madinov IV, Balabolkin MI, Markov DS. Main causes of hyperuricemia in diabetes mellitus. Ter Arkh. 2000; 72(2): 55-8.

31. Anwar MM, Meki AMR. Oxidative stress in streptozotocin-induced diabetic rats: effects of garlic oil and melatonin. Comp Biochem Physiol. 2003; 135(4): 539-47.

32. Whitton PD, Hems DA. Glycogen synthesis in perfused liver of streptozotocin diabetic rats. Biochem J. 1975; 150(2): 153-65.

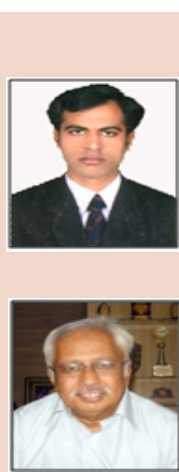

\section{ABOUT AUTHORS}

Dr. Rajesh Maheshwari: Presently working as Assistant Professor at Department of Pharmacy, Sumandeep Vidyapeeth, Vadodara. He has 6 years of teaching and 3 years of industrial experience. He has published 11 research papers and also presented several research papers in various conferences. He has guided more than 10 students for M.Pharm dissertation.

Dr. Ramachandran Balaraman: Presently working as professor of Pharmacology at Department of Pharmacy, Sumandeep Vidyapeeth, Vadodara, India \& formerly Professor \& Head at Pharmacy Department, The M S University of Baroda, India. He has 38 years of teaching experience and has published more than 125 research papers in international and national journals with $\mathrm{H}$-index of 24 and citation of more than 2000. He won several awards like Dr. Dhalla oration award; Dr. Lalita Kameshwaran oration award; Dr. Uvanas prize etc. More than 20 students got Ph. D under his guidance and he got the most prestigious award namely Fellow of Academy of Medical Sciences (FAMS) by the NAMS. He was also vice president of Indian Pharmacological Society for year 2007. 